Article

\title{
Quadruple Helix Models for Sustainable Regional Innovation: Engaging and Facilitating Civil Society Participation
}

\author{
Mona Roman ${ }^{1, *}$, Henry Varga ${ }^{2}$, Vladimir Cvijanovic ${ }^{2} \mathbb{D}$ and Alasdair Reid ${ }^{2} \mathbb{D}$ \\ 1 Metropolia University of Applied Sciences, 00920 Helsinki, Finland \\ 2 European Future Innovation System Centre, 1000 Brussels, Belgium; varga@efiscentre.eu (H.V.); \\ cvijanovic@efiscentre.eu (V.C.); reid@efiscentre.eu (A.R.) \\ * Correspondence: mona.roman@metropolia.fi
}

Received: 9 April 2020; Accepted: 4 June 2020; Published: 8 June 2020

check for updates

\begin{abstract}
Prior research has emphasized the importance of bringing together quadruple helix $(\mathrm{QH})$ actors (academia, industry, government and civil society) to strengthen regional innovation. The $\mathrm{QH}$ model forms an integral part of European innovation policy, which aims to create sustainable and inclusive growth in Europe. As part of this policy, European Union (EU) regions are to design and implement research and innovation strategies for smart specialization (RIS3) through the participatory entrepreneurial discovery process (EDP). Despite the strong emphasis on the QH model, the model is still far from a well-established concept in innovation research and policy, and civil society participation in RIS3 has remained low. Our paper aims to support regional governments to engage with and facilitate the participation of civil society in a territorial EDP based on two case studies from Finland and Sweden. It contributes to the literature on regional innovation systems through identifying mechanisms to foster the $\mathrm{QH}$ model and suggests lessons learnt for the operationalization of the QH model as part of RIS3.
\end{abstract}

Keywords: civil society; entrepreneurial discovery process; quadruple helix; regional innovation; smart specialization

JEL Classification: O35; O36; O38

\section{Introduction}

The regional innovation systems (RIS) approach draws on the literature on Marshallian industrial districts, economic geography, innovative milieux, learning regions, clusters and national systems of innovation. It emphasizes the importance of regions as key drivers of innovation (Asheim et al. 2011). Innovation is viewed as the outcome of interaction between a multitude of actors distributed over many different institutions and locations (Doloreux 2002). The quality and the performance of RIS is dependent on the knowledge interactions within and beyond the region (Tödtling and Trippl 2011). The RIS research field has been dominated by a focus on two major issues-the role of different organizations in producing and disseminating knowledge and the way those organizations interact with each other (Doloreux and Gomez 2017).

Prior research has defined RIS as a place in which two sub-systems of actors are engaged in interactive learning: first, a knowledge exploitation sub-system, which consists of mainly firms; second, a knowledge exploration sub-system, which consists of public and private research laboratories, universities and colleges, technology transfer agencies and vocational training organizations (Asheim et al. 2019; Cooke et al. 1998). These two sub-systems represent the core of the RIS, while also 
a wider definition exists that includes also organizations and institutions contributing to competence building and the labor market as well as institutions that represent framework conditions for promoting innovation (Lundvall 2010). The triple helix (TH) model, which forms a key concept in the RIS literature, describes regional development as the result of the interactions between three distinct actors-academia, industry and government (Etzkowitz and Leydesdorff 1995). Prior research on the TH model has determined the relationships between these three spheres, the functions of their interactions and the mechanisms to facilitate these interactions (Ranga and Etzkowitz 2013). While the TH model is a well-defined concept, RIS scholars disagree over the exact definition and conceptualization of the quadruple helix $(\mathrm{QH})$ model that also contain citizens and civil society as fourth group of actors (Cavallini et al. 2016; Grundel and Dahlström 2016; Ivanova 2014; Miller et al. 2018).

There is, nonetheless, a wide acceptance in the current RIS literature of the necessity of implementing the QH model in order to create sustainable innovations and growth (e.g., Carayannis and Campbell 2009; Carayannis and Rakhmatullin 2014; Foray et al. 2012; Ivanova 2014; Miller et al. 2018; Yawson 2009). The QH model is seen as playing an important role in fostering the shift from technical to social innovations (Carayannis and Rakhmatullin 2014; Foray et al. 2012) and strengthening democracy in the decision making of regional research and innovation strategies (Carayannis and Campbell 2009; Cavallini et al. 2016; Deakin et al. 2018). The QH model has been placed at the forefront of European innovation policy, in which RIS3 is an ex ante condition for the use of European Structural and Investment Funds (ESIF) by the European Union (EU) member states under the thematic objective of strengthening research, technological development and innovation. RIS3 is essentially a governance process comprising both design and implementation of regional innovation strategies. RIS3 is also gaining importance in the EU's neighborhood countries (Benner 2019a).

In the context of RIS3, the fourth helix has been defined as civil society, consisting of groups representing demand-side perspectives, such as innovation users and consumers, as well as non-profit organizations representing citizens and workers (Cavallini et al. 2016; Gianelle et al. 2016). The backbone of the smart specialization policy is the entrepreneurial discovery process (EDP), which can be defined as the prioritization of 'investment based on an inclusive and evidence-based process driven by stakeholders' engagement and attention to market dynamics' (Gianelle et al. 2016, p. 15). The participatory nature of the EDP means that the public and private sector must align their priorities for regional development (Benner 2019b). The effective EDP implementation requires the inclusion of civil society in RIS3 (Foray et al. 2012; Gianelle et al. 2016).

Nevertheless, while current RIS research and RIS3 policy emphasize the importance of involving civil society in territorial EDP, present practice fails to reflect these aims. Recent case studies and surveys have indicated that civil society participation in the context of RIS3 continues to be low (Aranguren et al. 2018; Benner 2019b; Kroll 2016; Marinelli and Forte 2017), and the regions have experienced difficulties in getting civil society groups involved (Guzzo et al. 2018). This means that the potential for QH innovation has remained largely untapped in RIS3 (Kroll 2016). Further knowledge would be needed to bridge the gap between the RIS3 policy and the practice.

The aim of this paper is to contribute to RIS3 policy and practice regarding the mechanisms through which governments can engage civil society and facilitate its participation in a territorial EDP with other $\mathrm{QH}$ actors. Our specific research questions are the following:

1. How can governments engage civil society actors in a territorial EDP?

2. How can governments facilitate the participation of civil society in a territorial EDP?

3. What are lessons learnt and conclusions for RIS3 policy and practice?

To address these questions, we conducted a study with two cases featuring early regional experiments to involve civil society in a territorial EDP. The first, the Wings and Roots project, was facilitated by three regions in Southern Finland, while the second, the Genius Loci project, was facilitated by the Sunne Municipality in the Värmland region of Sweden. Based on the two cases, our paper provides lessons learnt and conclusion for RIS3 policy and practice. 
Our paper is structured as follows. In section two, we provide a brief background of the $\mathrm{TH}$ model, after which we describe the main definitions and conceptualizations proposed for the $\mathrm{QH}$ model and refer briefly to quintuple helix model. The third section discusses the recent research on the QH model in the context of RIS3. In the fourth section we introduce our research methodology and the selection of the two case studies. The fifth section describes our regional cases and provides cross-case comparisons of how to engage and facilitate the participation of civil society in a territorial EDP. Finally, our paper concludes with key findings of the case studies and their policy implications for RIS3 in the future

\section{TH Model and Its Extensions to QH and Quintuple Helix}

The TH model is the focus of a significant body of research in the RIS literature, making it a well-established concept for exploring innovation dynamics and informing policy makers on how to support regional innovation (Cavallini et al. 2016). The TH model provides an analytical framework for examining regional innovation and economic development that arises from knowledge-based interactions between academia, industry and government. The key functions of a TH system are knowledge, innovation and consensus building, and prior research has identified several mechanisms for realizing these functions, such as building an integrated environment for university technology transfer and entrepreneurship (Ranga and Etzkowitz 2013).

The extension of the TH model to the QH innovation model has resulted in various definitions of the fourth helix, such as users of innovation, consumers, media- and culture-based public, public as users in an innovation-driven context, and citizens and civil society (Arnkil et al. 2010; Carayannis and Campbell 2009; Foray et al. 2012; Yawson 2009). The common denominator for these definitions is the recognition of citizens as an important stakeholder in innovation process. According to Leydesdorff and Etzkowitz (2003), civil society cannot be seen as distinct institutional sphere within the TH model, as the three specialized functional spheres of the model (university, industry and government) evolve within civil society. However, it is important to provide a mechanism to establish communication between university, industry and government with the civil society (Ivanova 2014).

Prior research has emphasized the importance of involving citizens and civil society in the innovation process. The advocates of the civil society emphasize democratic values as a part of the innovation process, which is not naturally inherent in the TH model (Carayannis and Campbell 2009; Cavallini et al. 2016; Deakin et al. 2018). The prior literature has highlighted several advantages of the QH model over the TH model in the creation of sustainable innovation. First, the QH model can complement and enhance the TH model by providing 'bottom-up' insights from civil society to complement 'top-down' views from university, industry and government in regional development (Carayannis and Rakhmatullin 2014). Second, the involvement of civil society supports the creation of social innovations, and legitimation and justification for innovations (Carayannis and Campbell 2009; Carayannis and Rakhmatullin 2014; Foray et al. 2012; Yawson 2009). Civil society is frequently the end user of innovation and exerts a strong influence over the generation of knowledge and technologies through its demand function (Carayannis and Grigoroudis 2016). Third, the engagement of civil society in designing regional development strategies and determining strategic priorities is essential for their commitment to and ownership of a development agenda (Carayannis and Campbell 2009).

While the TH model can be formed in one unique way, the QH model can in fact be composed in a number of different ways according to their topological or symmetry structure (Ivanova 2014). Arnkil et al. (2010) have classified four different types of QH models based on who initiates and leads the innovation process: academia, industry, government or citizens. In Arnkil et al.'s (2010) model, citizens can be active stakeholders who are able to initiate and lead innovation processes themselves. In a similar vein, Carayannis and Rakhmatullin (2014) highlight that citizens can have the power to suggest new types of innovation, not only support the development process. According to Aranguren et al. (2018), with regards the innovation process, citizens and civil society can play either a consultative or participatory role, including co-production of knowledge with other innovation stakeholders. 
Going a step further, Carayannis and Campbell (2010) present a quintuple helix model by adding natural environments as the fifth helix. In an interview, Caryannis and Campbell described the TH model as including the core processes of the knowledge economy, while the QH model incorporates the knowledge society and democracy and the quintuple model the environmental context of society and the economy (Carayannis and Campbell 2014).

\section{Quadruple Helix Model and Smart Specialization}

The QH model is an integral element in the design of smart specialization strategies as fostering knowledge creation and exchange by bringing together firms, research centers, independent inventors and lead users (Carayannis and Grigoroudis 2016). The smart specialization policy process should create opportunities and incentives for stakeholders to communicate their knowledge through participating in a territorial EDP (Foray 2016). All QH actors play a role in the EDP, and it is important to underline that no single party is more important than another (Rodríguez-Pose and Wilkie 2016). Moreover, collaboration between the various QH actors should be continuous throughout the different stages of the RIS3 policy-making process: agenda setting, policy formulation, decision making, implementation and evaluation (Gianelle et al. 2016; Marinelli and Forte 2017).

The role of civil society and citizens is seen as especially valuable for strengthening social innovations in regions (Carayannis and Campbell 2009; Carayannis and Rakhmatullin 2014; Foray et al. 2012). Social innovations can be defined as the development and implementation of new ideas (products, services, and models) to meet social needs and create new social relationships or collaborations (European Commission 2013). Social innovations indeed are important in fostering the creation of new social practices (Cajaiba-Santana 2014). Social cohesion or social change is a notable theme, and social innovation can be understood as empowering citizens and fostering the relations between local civil communities and their governing bodies (van der Have and Rubalcaba 2016). In addition, the role of civil society is crucial in addressing climate change and strengthening ecological innovations as part of smart specialization (Foray et al. 2012). Furthermore, citizens as consumers and innovation users are needed to represent the demand-side perspective on innovations in territorial EDP (Foray et al. 2012). Civil society is thus an important stakeholder in regional innovation process such as RIS3 in fostering the development of innovations addressing sustainable development goals.

While the emphasis in the literature on the QH model in the RIS, and particularly RIS3, has been strong, few studies have focused on conceptualizing the $\mathrm{QH}$. This is despite the many empirical studies related to the TH model that have been conducted in the context of RIS3 (e.g., Morgan 2016; Ranga and Garzik 2015; Todeva and Ketigidis 2017; Virkkala et al. 2017). A study by Schoonmaker and Carayannis (2013) indicated that most universities still operate within TH structures despite recent innovation policies advising the application of a $\mathrm{QH}$ structure. Moreover, a recent case study by Benner (2019b) focusing on RIS3 design processes in Austria, Italy, Slovenia and Croatia did not mention civil society or citizens as participants in a territorial EDP. Furthermore, in a comparison of eight European regions, Aranguren et al. (2018) were largely unable to identify the necessary interaction between regional stakeholders required for a truly participatory EDP. Indeed, a survey by Kroll (2016) found that RIS3 was focused more on technology/business sectors than societal challenges.

Previous studies have claimed, moreover, that a well-functioning TH may hinder rather than favor the development of the QH system (Grundel and Dahlström 2016; MacGregor et al. 2010). Consequently, engaging civil society and facilitating their participation in the regional innovation system is likely to require new ways of interacting between helices which go beyond simply inviting civil society to work alongside the other stakeholders (Horelli et al. 2015). Embedding crowd-sourcing and -funding capabilities into instruments and initiatives is an example of how to empower the civil society in the development of RIS3, thereby potentially allowing faster, broader, cheaper, and more resilient learning-to-learn and learning-to-learn-how-to-learn dynamics (Carayannis and Grigoroudis 2016). Recent research has shown that the use of digital platforms may boost the impact of stakeholders' engagement (Panori et al. 2020). 
Based on a recent systematic literature review of university technology transfer from a $\mathrm{QH}$ perspective, Miller et al. (2018) concluded that the QH model has remained a top down/macro agenda. Consequently, insufficient knowledge exists on how to implement it at the meso and micro levels. In the context of RIS3, prior research has urged future studies to examine the mechanisms required to achieve wide and effective involvement of stakeholders in the selection of innovation priorities (Carayannis and Rakhmatullin 2014). Our paper responds to the above need recognized in prior research. Our research focuses on government-led QH innovation model in which the government facilitates the QH interactions. Figure 1 illustrates the conceptual framework including our research questions (RQs) that guide our case study research.

\section{From TH to QH Innovation model}

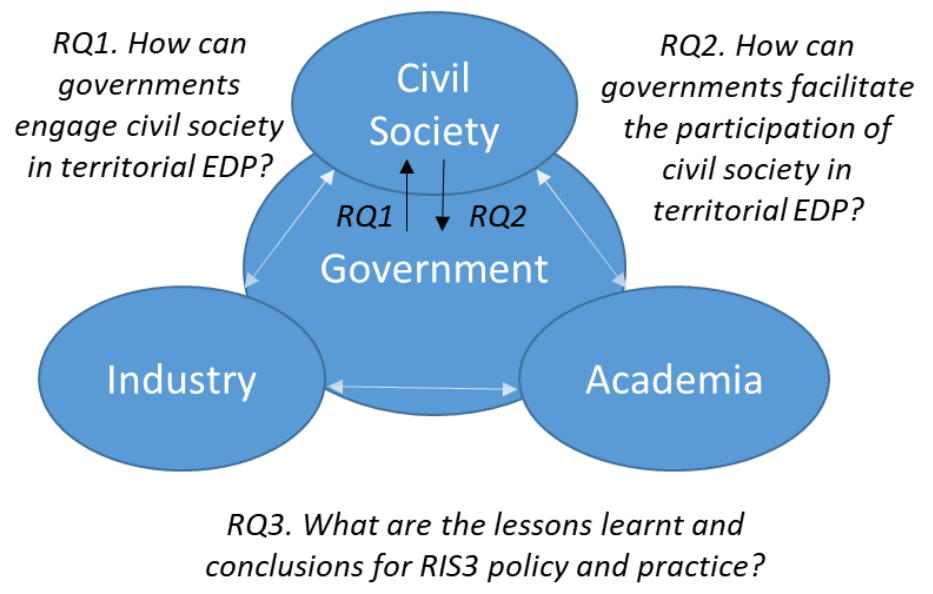

Figure 1. Conceptual framework.

\section{Research Methods and Data}

Our paper is based on case studies. Case studies are suitable for studying phenomena for which little prior knowledge exists or where current perspectives are conflicting and confusing, their purpose being to collect evidence to generate novel insights (Eisenhardt 1989; Langley and Abdallah 2011). In order to select the cases for our study, we utilized our existing contacts with public authorities in Europe, partly based on the Horizon 2020 project (ONLINE-S3) in which we examined the characteristics of RIS3 processes in 30 European regions ${ }^{1}$. Our selection criteria for the cases was that they should represent early regional experiments to involve civil society in a territorial EDP. We selected two cases that met the criteria: the collaborative foresight project Wings and Roots, initiated by three regions in Southern Finland, and an EU co-funded project, Genius Loci-local talents, in the Värmland region of Sweden.

We collected primary data through four semi-structured interviews with the public authorities in the Helsinki-Uusimaa Regional Council and the Sunne Municipality. The interviews lasted approximately one hour and were conducted in the summers of 2017 and 2018. We utilized a common semi-structured questionnaire to allow the collection of comparable information about the cases but also leave room for interviewees to express their views openly. The questionnaire focused on how to facilitate the engagement and the participation of civil society in a territorial EDP.

In addition, we utilized secondary data from regional reports and documents related to the case projects. Using secondary data is also a means to enhance the validity of research findings through the triangulation of data sources (Yin 2009). For the Wings and Roots and Genius Loci projects, we utilized

$1 \quad$ Further information of the project available at www.onlines3.eu. 
regional reports that were openly available on the website of the regional/municipal authority. They describe the methods and key outcomes of the two projects (Helsinki-Uusimaa Regional Council 2013; Sunne Municipality 2011, 2014, 2018).

In addition, we wrote interview memos following the research questionnaire structure to enable consistent cross-case comparison. The interview memos were then shared with the respective interviewees to allow them to correct any possible interpretation biases. All identifying information about the interviewees was subsequently anonymized in the notes. Next, we compared the interview notes and the project reports and documents across the two cases to identify the differences and similarities between the QH models applied. Finally, we developed conclusion and lessons learnt for RIS3 policy and practice regarding how to operationalize the $\mathrm{QH}$ approach.

\section{Information on Case Regions}

Finland and Sweden have been characterized as innovation leaders in the European Innovation Scoreboard (EIS) measurement. According to the EIS 2019, Finland and Sweden received especially high scores for an innovation friendly environment, human resources, research systems and firm investments in research and development $(R \& D)^{2}$. Both Sweden and Finland have a long tradition of close collaboration and interaction between the stakeholders of university, industry and government. In the Finnish research and innovation system development efforts in the 2010s have focused on strengthening participatory innovation (Kautonen et al. 2017; Uotila et al. 2012). In Sweden, there have been significant efforts to strengthen the independence of non-governmental organizations (NGOs), their active voice and their role as opinion makers. For instance, in 2008 a national agreement was signed in the social care sector to facilitate the increasing role of NGOs, which was followed by a new agreement in 2018 to open more policy areas for dialogue and consultation.

Our case regions are the Helsinki-Uusimaa region of Finland and the Värmland region of Sweden. Helsinki-Uusimaa is located on the south coast of Finland and is home to around 1.7 million inhabitants, of whom close to 1 million live in the Helsinki capital region. The tasks of the Regional Council involve, among others, regional development, including RIS3 strategy design and implementation, land-use planning and the promotion of local and regional interests in general. The biggest industrial sector in the Helsinki-Uusimaa region is services (e.g., trade, health and social care, education, ICT), accounting for approximately $82 \%$ of all industries (Helsinki-Uusimaa Regional Council 2019, p. 4) ${ }^{3}$. The smart specialization priority areas in Helsinki-Uusimaa are urban cleantech, health and wellness, digitalizing industry and the citizen city ${ }^{4}$.

The Värmland region is located in central Sweden, bordering Norway, and has a population of 282,000 inhabitants. The region is responsible for all Värmland's publicly funded regional development, health care, culture, education and public transport. The largest industrial sector in the region is the paper and pulp industry, with the steel and raw material sectors representing two other important industries (Värmland Region 2015). The smart specialization priority areas in the Värmland region are the forest-based bioeconomy, digitalization of welfare services, advanced manufacturing and complex systems, nature, culture, and place-based digitalized experiences and system solutions with photovoltaics (Värmland Region 2015).

The Regional Innovation Scoreboard 2019 ranks the Helsinki-Uusimaa region the most innovative region in EU, followed by the Stockholm region and the Copenhagen region. Helsinki-Uusimaa is characterized as an innovation leader, while the Värmland region as a strong innovator ${ }^{5}$. While both regions have designed their smart specialization strategies through a widely collaborative

\footnotetext{
2 Further information at https://ec.europa.eu/growth/industry/innovation/facts-figures/scoreboards_en.

3 Further information available at https://www.uudenmaanliitto.fi/en/helsinki-uusimaa_region/helsinki-uusimaa_region_ facts.

4 Further information available at https://helsinkismart.fi/.

5 Further information available at https://ec.europa.eu/commission/presscorner/detail/en/ip_19_2991.
} 
process, earlier research has emphasized that further actions are needed to widen and deepen the participation of civil society in the RIS3 strategy design process (Grundel and Dahlström 2016; Roman and Nyberg 2017).

\section{Results}

The selected cases feature initial experiments of the local and regional governments to enhance the capabilities and competences of regional $\mathrm{QH}$ stakeholders to act according to the $\mathrm{QH}$ innovation model. Both projects were the first of their kind for the governments and served to create basis for the $\mathrm{QH}$ innovation model used in the regions today. The case study projects were not directly related to regional RIS3 process but have contributed to the formulation of the current RIS3 practices in terms of stakeholder engagement and collaboration in the regions.

Below, we first describe the cases and present their key findings as regards to how governments can engage and facilitate the participation of civil society in territorial EDP and the outcomes of the $\mathrm{QH}$ collaboration. Then, we provide a cross-case comparison based on which we derive lessons learnt and conclusions for RIS3 policy and practice.

\subsection{Case-Wings and Roots}

The Wings and Roots project was facilitated by three regional councils in Southern Finland (Helsinki-Uusimaa, Häme and Päijät-Häme) in Autumn 2012. The regions together have a population of approximately 2 million inhabitants. The joint project aimed to develop a shared vision and identify common development themes to solve societal challenges among the three regions and thus create pathways for increased future collaboration. The project experimented with new online methodologies, such as crowdsourcing, to involve citizens in the project. The aim of crowdsourcing was to seek consultation from different groups of citizens and enhance the dialogue between citizens, decision makers and traffic experts in relation to future mobility preferences.

The key mechanism for the engagement of civil society in Wings and Roots project was to invite a target group of civil society representatives (one elementary school class of pupils, one high school class of students and one senior citizens organization) to participate in the crowdsourcing pilot together with regional policy makers and experts to define future mobility choices. Each group received an introduction to the work through a face-to-face meeting with the project facilitator and continued the work through online assignments and discussion. Furthermore, the project set up an interactive website to engage citizens and civil society to participate in the project. On the website, anyone could contribute to the project through suggesting improvements to the regional development visions and vote for the five most important visions. According to the project facilitators, voting lowered the threshold for contributing on the website and the hundreds of votes cast supported the selection of regional priorities. Voting was also used in the crowdsourcing pilot to facilitate the participation of target group representatives of civil society to collect their views regarding future mobility preferences and initiate discussions between the students, pupils, senior citizens, experts and decision makers on the underlying reasons for different mobility choices.

According to an interviewee, the participants in the crowdsourcing pilot were motivated to collaborate with the public sector, as it offered them the possibility to influence regional development and thus contribute to a common better future. It proved challenging though to sustain the participants' attention throughout the project. According to the project facilitators, arranging physical meetings and events to complement the online working method would have been needed to sustain the attention of participants. Tying the task assigned to the participants more closely to the experiences and preferences of each target group would have encouraged the different groups to contribute. Furthermore, the senior citizens involved in the project would have required additional guidance on the use of crowdsourcing tools, as they were less experienced in IT than the other groups. Finally, the traffic experts felt that the questions in the crowdsourcing tool were citizen-centric, and thus they tended merely to follow the discussions rather than actively participating in them. 
Over the course of four months, 700 decision makers and experts attended workshops, 12,000 people visited the project website, and a pre-defined group of 100 people worked in the crowdsourcing pilot sharing experiences and views related to future mobility solutions. By engaging with civil society actors, the projects succeeded in attracting individuals who would not have typically contributed to regional development activities. The crowdsourcing experiment of the Wings and Roots project showed that for a narrowly defined challenge it is possible to generate an in-depth understanding with a selected target group. According to the project facilitators, citizens felt it important that different groups were able to influence future regional planning, and decision makers were interested to hear and act upon the views of citizens.

The results of the Wings and Roots project served as the basis for the RIS3 strategy in the Helsinki-Uusimaa region for the period 2014-2020 (Helsinki-Uusimaa Regional Council 2015), with the views collected from a large group of regional actors in the project serving as the foundation for developing a shared vision within the RIS3 strategy design process. According to our interviewee in Helsinki-Uusimaa regional council, the lessons learnt from the crowdsourcing experiment served as a source of inspiration and a model as regards to how to engage and facilitate the participation of civil society in RIS3 process.

\subsection{Case-Genius Loci}

The Genius Loci project was facilitated by the Sunne Municipality in the Värmland region in 2008-2011. The aim of the project was to develop a growth-creating model for the region and its municipalities, strengthen existing companies and stimulate entrepreneurship by creating new methods for participation and cooperation between different groups (researchers, enterprises, the public sector, associations and individuals). These methods were developed by focusing on local assets, local talents, local traditions and trust. The role of the civil society in the project took different forms, from receiving training and information and participating in local development activities to engaging in dialogue with other actors, including universities, research institutes, companies and the public sector, and finally participating in the co-creation of the local growth-creating model. The three-year-long EU co-funded project ${ }^{6}$ involved 4500 people in different workshops, meetings, events, study trips and new meeting spaces.

In the beginning of the Genius Loci project citizens and civil society representatives were invited by the municipality to meetings and information sessions. The latter was aimed at capacity building amongst citizens to contribute in local development. An important part of the meetings was to carefully listen to the views of the citizens and enhance their ability adopt an active role in the development of the municipality. Here, an interviewee emphasized the importance of creating a welcoming atmosphere that inspired and encouraged people, regardless of their background, to suggest new ideas. Furthermore, she emphasized the significance of involving participants at an early stage of the project to allow them to contribute more effectively to the project outcomes. The citizens and civil society were also engaged in the project through setting up a project website, writing blogs, and by organizing popular events for the public.

The Genius Loci project utilized a wide range of methods to facilitate the participation of civil society in co-creation with academia, business and public sector representatives. For instance, the Sunne Municipality created new meeting places for different regional actors to allow them to meet freely and discuss future issues and municipal strategies. Furthermore, it arranged study visits where different actors could learn from experience elsewhere in Sweden and abroad. It also arranged co-creation workshops, meetings and events with entrepreneurs, students, associations, the public and the municipal management and employees where the participants could discuss and learn from each other. In the Genius Loci project, civil society actors received many opportunities to provide their

6 Through the European Regional Development Fund (ERDF). 
development ideas. For example, the Ski Sunne event, which attracted 3000 participants, included an 'opinion tent' where citizens could talk to politicians and offer their ideas. These ideas were then assessed, and responses were published on the Internet and sent directly to schools. Furthermore, throughout the entire project, the Sunne Municipality regularly communicated the achievements and failures of their collaborative work to stakeholders. According to our interviewee, this was an important means of creating trust and building confidence between the QH stakeholders.

The Genius Loci project resulted in the creation of a 'Sunne model', which formed the basis for the development and the implementation of the Sunne municipal strategy (2014-2025). Today, the Sunne model forms an integral part of the municipality: all employees in the area are informed about it, and an annual award is granted for the workplace that best utilizes the Model. The Sunne model has also contributed to the creation of a brochure, Citizen Dialogue (Sunne Municipality 2018). The brochure informs citizens of how they can contribute to municipal development. The Genius Loci project involved over 4500 people, 250 businesses and 29 municipalities and public sector organizations. According to our interviewee from Sunne Municipality, the Genius Loci project has inspired and served as a model of implementing QH collaboration in Värmland region and the neighboring regions and countries.

\subsection{Cross-Case Comparison}

Table 1 provides a cross-case comparison of the two cases as regards to the key methods and outcomes of civil society participation in territorial EDP. While the engagement of civil society was narrower and more short term in the Wings and Roots project than in the Genius Loci project, the process of engaging civil society shared many similarities between the case projects. Both projects started with inviting citizens and civil society representatives for information meetings and focused on building the capacity of citizens to contribute for local/regional development. While the Wings and Roots project primarily experimented with online methods to facilitate the participation of civil society, the Genius Loci project utilized a wider range of methods. For instance, the Sunne Municipality established new meeting places, study trips, workshops and events in which QH stakeholders could interact with each other and provided feedback to citizens as regards to their suggested new ideas for regional development. Furthermore, both projects provided the opportunity for civil society to influence regional development and the selection of regional innovation priorities.

Table 1. Comparison of the case study findings.

\begin{tabular}{|c|c|c|}
\hline Project & Wings and Roots & Genius Loci \\
\hline $\begin{array}{l}\text { Key methods to } \\
\text { engage civil } \\
\text { society }\end{array}$ & $\begin{array}{l}\text { - A pre-defined target group invited } \\
\text { for a crowdsourcing pilot } \\
\text { Face-to-face meeting to introduce } \\
\text { the pilot and train participants to } \\
\text { use the crowdsourcing tools } \\
\text { - Development of an interactive } \\
\text { project website and a } \\
\text { crowdsourcing tool }\end{array}$ & $\begin{array}{l}\text { Organisation of public meetings and } \\
\text { information sessions with focus on } \\
\text { building the capacity of citizens to } \\
\text { contribute in the project } \\
\text { Information provided in the project } \\
\text { website, a blog, and via the media and by } \\
\text { organising popular events for the public }\end{array}$ \\
\hline $\begin{array}{l}\text { Key methods to } \\
\text { facilitate civil } \\
\text { society } \\
\text { participation }\end{array}$ & $\begin{array}{l}\text { - Crowdsourcing the views of } \\
\text { students, pupils and senior citizens } \\
\text { and supporting the discussions } \\
\text { between the different groups of } \\
\text { civil society, traffic experts } \\
\text { and politicians } \\
\text { - Open interaction through a website } \\
\text { with the material produced in } \\
\text { workshops and the possibility to } \\
\text { suggest improvements } \\
\text { Voting to support prioritisation } \\
\text { among different QH actors }\end{array}$ & $\begin{array}{l}\text { - New meeting places established for } \\
\text { different groups } \\
\text { - Study trips to learn from experience in } \\
\text { other parts of the Sweden and abroad } \\
\text { - Workshops for diverse groups to learn } \\
\text { from each other } \\
\text {-Opinion tent' to collect ideas and enable } \\
\text { - } \quad \begin{array}{l}\text { discussion between different groups } \\
\text { received and informing on } \\
\text { joint achievements }\end{array}\end{array}$ \\
\hline
\end{tabular}


Table 1. Cont.

\begin{tabular}{|c|c|c|}
\hline Project & Wings and Roots & Genius Loci \\
\hline $\begin{array}{l}\text { Key outcomes } \\
\text { of civil society } \\
\text { participation }\end{array}$ & $\begin{array}{l}\text { - Increased understanding of } \\
\text { regional experts and decision } \\
\text { makers as regards to views } \\
\text { of citizens } \\
\text { Increased openness and } \\
\text { collaboration between citizens and } \\
\text { the public sector } \\
\text { Enhanced possibility for citizens to } \\
\text { influence regional development } \\
\text { - Use of the results of the project as } \\
\text { the basis for development of a RIS3 } \\
\text { strategy (2014-2020) in the } \\
\text { Helsinki-Uusimaa region } \\
\text { Documentation of the process and } \\
\text { lessons learnt in an open-access } \\
\text { regional report. }\end{array}$ & $\begin{array}{l}\text { - Increased understanding of the public } \\
\text { authorities as regards to the ways of acting, } \\
\text { views on and expectations of citizens and } \\
\text { civil society for the municipality } \\
\text { Increased trust, openness and } \\
\text { collaboration between civil society and } \\
\text { other QH actors } \\
\text { Development of a collaborative Sunne } \\
\text { model used in the development and the } \\
\text { implementation of the Sunne municipality } \\
\text { strategy (2014-2025) } \\
\text { - All new employees in the municipality } \\
\text { informed about the Sunne model } \\
\text { Annual award for the workplace that best } \\
\text { - } \begin{array}{l}\text { citizes the Sunne model } \\
\text { citizens to contribute brochure to encourage } \\
\text { of the municipality }\end{array}\end{array}$ \\
\hline
\end{tabular}

Source: case interviews and secondary data from Helsinki-Uusimaa Regional Council (2013) and Sunne Municipality $(2011,2014,2018)$.

Nevertheless, while the two projects featured similar mechanisms for engaging and facilitating the participation of civil society and citizens, the range of activities included in the Genius Loci project was much wider than that of the Wings and Roots project due to the projects' different objectives. While the Genius Loci project aimed to develop a 'Sunne model' for continuous QH collaboration in the Sunne Municipality, the Wings and Root project aimed to promote consultation and feedback from citizens in order to develop a shared vision and common development themes for solving societal challenges in the three regions in Southern Finland.

The main outcomes of civil society participation in both projects were increased openness and collaboration between the different $\mathrm{QH}$ actors. The projects succeeded in attracting new actors for local/regional development activities. In addition, both projects succeeded in increasing understanding between different stakeholder groups. They both served as a model and a source of inspiration to implement increased $\mathrm{QH}$ collaboration in regional research and development processes including RIS3. The two cases showed the important role of the government to facilitate the $\mathrm{QH}$ interactions in territorial EDP and thus to promote inclusive and sustainable innovation and growth.

\subsection{Implications for RIS3 Policy and Practice}

Prior literature has emphasized the importance of implementing $\mathrm{QH}$ innovation model to strengthen the creation of social and ecological innovations in RIS3 (Foray et al. 2012). The two cases provided several lessons learnt that can be applied to foster the engagement and participation of civil society in RIS3 process. First, RIS3 facilitators need to carefully listen to the various groups of civil society in order to understand their specific needs and interests, and thus to understand their viewpoint and possibility to contribute in the design of RIS3. Furthermore, it is important to modify the communication approach to be in line with the needs of various groups of civil society representatives. Second, it is important to clearly communicate to the civil society the different ways they can contribute to regional development and involve them in RIS3 development at an early stage to ensure the maximum input in strategy design. Third, regional governments should facilitate interactions between regional QH actors in RIS3 design process through establishing both physical and virtual collaboration spaces and tools and providing training on how to use them. Finally, in order to capture the benefits of the QH model and motivate $\mathrm{QH}$ actors to participate in a territorial EDP, it is crucial to involve civil society actors in decision making with other regional innovation actors on regional innovation 
priorities. The cases showed that influencing the local/regional innovation and development provides a key motivation of civil society to participate in territorial EDP.

\section{Conclusions}

Prior research has suggested the $\mathrm{QH}$ innovation model as a way to foster social and ecological innovation, ensure demand and legitimation for regional innovations and enhance democracy in regional decision making (Carayannis and Campbell 2009; Carayannis and Rakhmatullin 2014; Carayannis and Grigoroudis 2016; Cavallini et al. 2016; Foray et al. 2012; Yawson 2009). Based on our case studies, we identified various mechanisms that governments can utilize to facilitate the engagement and participation of civil society in territorial EDP, and thus support the operationalization of the $\mathrm{QH}$ innovation model. While prior research has identified mechanisms for facilitating interaction between TH stakeholders (Ranga and Etzkowitz 2013), our research contributes to the RIS literature on the mechanisms governments can use to facilitate $\mathrm{QH}$ interactions in territorial EDP.

In contrast to prior research on RIS, we found that a well-functioning TH model does not necessarily hinder the implementation of the QH model. This is because both governments in our case study regions, Helsinki-Uusimaa and Värmland, were able to facilitate QH innovation model, while they have had a long experience of successful TH collaboration in the regions. However, we can notice based on the case studies that regional government must employ a different approach to engage citizens and civil society from that used with TH (academia, industry and public sector) stakeholders. From the beginning, it is important to adapt the approach according to the needs and requirements of citizens and civil society when approaching these groups. Moreover, it is important to pay attention to the fact that the 'fourth helix' comprises a heterogeneous group of actors who must themselves be approached differently.

While prior literature on smart specialization policy emphasizes the importance of the QH model, the engagement and the participation of the civil society in RIS3 has remained scarce (Aranguren et al. 2018; Benner 2019b; Kroll 2016; Marinelli and Forte 2017). Our case study contributes to the operationalization of the QH model in the context of RIS3 by presenting concrete steps and examples for how governments can engage and facilitate the participation of different civil society groups in a territorial EDP. As to key implications for RIS3 policy and practice, our study emphasizes the key role of the government to facilitate territorial EDP and demonstrates the importance of targeted communication approach for different groups of civil society representatives, the establishment of physical and virtual collaboration spaces and tools to facilitate the QH collaboration in RIS3 and the involvement of the civil society in regional decision making on innovation priorities. Our case study reveals that the main motivation of civil society to participate in regional development derives from the possibility to contribute to regional decision making as civil society's inputs are taken into account.

The main limitation of our paper is the focus on relatively particular cases. Prior research has indicated that less innovative regions suffer from a lack of helix maturity, hampering effective implementation of the EDP and the QH approach (Cavallini et al. 2016). Both our case regions were innovative areas with long experience of the TH innovation model. It is also important to note that our case regions are located in Northern Europe, which is politically, economically, socio-culturally and technologically rather homogeneous compared to many other parts of Europe. The governmental and public agencies in Northern Europe play an active role in regional innovation systems (Asheim et al. 2019). This may also have exerted a strong influence on the implementation of the QH model.

For future research, we recommend the validation of our findings through additional case studies in other regions. It would also be important to conduct more in-depth assessments with regards to the impact of civil society interactions with other TH stakeholders on regional innovation so as to provide further guidance to RIS3 policy makers. Furthermore, it would be important to also examine mechanisms to implement $\mathrm{QH}$ innovation models led by QH actors other than the government-by academia, industry and civil society—and the contexts for these interactions. For practitioners, we 
recommend the application of our findings in the context of RIS3 design and the sharing of lessons learnt to encourage and advise other regional governments on the means of facilitating the $\mathrm{QH}$ innovation model. This would be highly important in order to strengthen social and environmental innovation and thus to contribute to inclusive and sustainable growth in Europe and elsewhere.

Author Contributions: Conceptualization, M.R., methodology, M.R., H.V.; case investigation M.R. (Finland), H.V. (Sweden); writing—original draft preparation, M.R., H.V., V.C.; writing—review and editing, M.R., H.V., V.C., A.R. All authors have read and agreed to the published version of the manuscript.

Funding: This research has received funding from the European Union's Horizon 2020 Research and Innovation Programme under grant agreement No. 710659, ONLINE-S3.

Acknowledgments: We are indebted to the interviewees from Helsinki-Uusimaa Regional Council and the Sunne Municipality for sharing their experiences with us.

Conflicts of Interest: The authors declare no conflict of interest. The funders had no role in the design of the study; in the collection, analyses, or interpretation of data; in the writing of the manuscript, or in the decision to publish the results. This article reflects only the authors' views. Neither the Research Executive Agency nor the European Commission is responsible for any use that may be made of the information it contains.

\section{References}

Aranguren, Mari José, Edurne Magro, Mikel Navarro, and James R. Wilson. 2018. Governance of the territorial entrepreneurial discovery process: Looking under the bonnet of RIS3. Regional Studies 53: 451-61. [CrossRef]

Arnkil, R., A. Järvensivu, P. Koski, and T. Piirainen. 2010. Exploring Quadruple Helix. Tampereen yliopistopaino Oy Juvenes Print: Tampere.The CLIQ. Available online: http://urn.fi/urn:isbn:978-951-44-8209-0 (accessed on 5 June 2020).

Asheim, Bjorn T., Helen Lawton Smith, and Christine Oughton. 2011. Regional Innovation Systems: Theory, Empirics and Policy. Regional Studies 45: 875-91. [CrossRef]

Asheim, Bjørn T., Arne Isaksen, and Michaela Trippl. 2019. An Advanced Introduction to Regional Innovation Systems. Cheltenham: Edward Elgar.

Benner, Maximilian. 2019a. Industrial Policy in the EU and Its Neighbourhood: Learning from Policy Experimentation. Economies 7: 44. [CrossRef]

Benner, Maximilian. 2019b. Smart specialization and institutional context: The role of institutional discovery, change and leapfrogging. European Planning Studies 27: 1791-810. [CrossRef]

Cajaiba-Santana, Giovany. 2014. Social innovation: Moving the field forward. A conceptual framework. Technological Forecasting and Social Change 82: 42-51. [CrossRef]

Carayannis, Elias G., and David F. J. Campbell. 2009. Mode 3' and 'Quadruple Helix': Toward a 21st century fractal innovation ecosystem. International Journal of Technology Management 46: 201. [CrossRef]

Carayannis, Elias G., and David F. J. Campbell. 2010. Triple Helix, Quadruple Helix and Quintuple Helix and how do knowledge, innovation and the environment relate to each other? A proposed framework for a trans-disciplinary analysis of sustainable development and social ecology. International Journal of Social Ecology and Sustainable Development 1: 41-69. [CrossRef]

Carayannis, Elias G., and David F. J. Campbell. 2014. Transition from the Triple Helix to N-Tuple Helices? An interview with Elias G. Carayannis and David F. J. Campbell (interviewer, Woo Park, H.). Scientometrics 99: 203-7.

Carayannis, Elias, and Evangelos Grigoroudis. 2016. Quadruple Innovation Helix and Smart Specialization: Knowledge Production and National Competitiveness. Foresight and STI Governance 10: 31-42. [CrossRef]

Carayannis, Elias G., and Ruslan Rakhmatullin. 2014. The quadruple/quintuple innovation helixes and smart specialisation strategies for sustainable and inclusive growth in Europe and beyond. Journal of the Knowledge Economy 5: 212-39. [CrossRef]

Cavallini, Simona, Rosella Soldi, Julia Friedl, and Margherita Volpe. 2016. Using the Quadruple Helix Approach to Accelerate the Transfer of Research and Innovation Results to Regional Growth. Brussels: European Union Publications. [CrossRef]

Cooke, Philip, Mikel G. Uranga, and Goio Etxebarria. 1998. Regional systems of innovation: An evolutionary perspective. Environment and Planning A 30: 1563-84. [CrossRef] 
Deakin, Mark, Luca Mora, and Alasdair Reid. 2018. The research and innovation of smart specialisation strategies: The transition from the triple to quadruple helix. Paper presented at the Social and Economic Conference, Rome, Italy, March 1-2.

Doloreux, David. 2002. What we should know about regional systems of innovation. Technology in Society 24: 243-63. [CrossRef]

Doloreux, David, and Igone Porto Gomez. 2017. A review of (almost) 20 years of regional innovation systems research. European Planning Studies 25: 371-87. [CrossRef]

Eisenhardt, Kathleen M. 1989. Building theories from case study research. Academy of Management Review 14: 532-50. [CrossRef]

Etzkowitz, Henry, and Loet Leydesdorff. 1995. The Triple Helix: University-Industry-Government Relations: A Laboratory for Knowledge-Based Economic Development. EASST Review 14: 14-19.

European Commission. 2013. Guide to Social Innovations. Available online: https://ec.europa.eu/regional_policy/ sources/docgener/presenta/social_innovation/social_innovation_2013.pdf (accessed on 5 June 2020).

Foray, Dominique. 2016. On the policy space of smart specialization strategies. European Planning Studies 24: 1428-37. [CrossRef]

Foray, Dominique, John Goddard, Xabier Goenaga Beldarrain, Mikel Landabaso, Philip McCann, Kevin Morgan, Claire Nauwelaers, and Raquel Ortega-Argilés. 2012. Guide to Research and Innovation Strategies for Smart Specialisation. Brussels: European Commission.

Gianelle, C., D. Kyriakou, C. Cohen, and M. Przeor. 2016. Implementing Smart Specialisation: A Handbook. Brussels: European Commission, EUR 28053 EN. [CrossRef]

Grundel, Ida, and Margareta Dahlström. 2016. A Quadruple and Quintuple Helix Approach to Regional Innovation Systems in the Transformation to a Forestry-Based Bioeconomy. Journal of the Knowledge Economy 7: 963-83. [CrossRef]

Guzzo, Fabrizio, Carlo Gianelle, and Elisabetta Marinelli. 2018. Smart Specialisation at Work: The Policy Makers' View on Strategy Design and Implementation. JRC Technical Reports JRC114141. Seville: Joint Research Centre.

Helsinki-Uusimaa Regional Council. 2013. Siivet ja Juuret_Laajan Metropolialueen Tulevaisuustarkastelu. Available online: https://www.uudenmaanliitto.fi/files/6314/Siivet_ja_juuret_-_Laajan_metropolialueen_ tulevaisuustarkastelu_C69-2013.pdf (accessed on 5 June 2020).

Helsinki-Uusimaa Regional Council. 2015. Smart Specialisation in the Helsinki-Uusimaa Region. Helsinki: Helsinki-Uusimaa Regional Council. Available online: https:/www.uudenmaanliitto.fi/files/16166/ Smart_Specialisation_in_Helsinki-Uusimaa_Region_-_Research_and_Innovation_Strategy_for_Regional_ Development_2014-2020_B_51_-_2015.pdf (accessed on 5 June 2020).

Helsinki-Uusimaa Regional Council. 2019. Helsinki-Uusimaa Region in Figures, 2019. Available online: https://issuu.com/uudenmaanliitto/docs/helsinki-uusimaa_region_in_figures_30cc2b377c71d0 (accessed on 5 June 2020).

Horelli, Liisa, Joanna Saad-Sulonen, Sirkku Wallin, and Andrea Botero. 2015. When Self-Organization Intersects with Urban Planning: Two Cases from Helsinki. Planning Practice and Research 30: 286-302. [CrossRef]

Ivanova, Inga. 2014. Quadruple helix systems and symmetry: A step towards helix innovation system classification. Journal of the Knowledge Economy 5: 357-69. [CrossRef]

Kautonen, Mika, Rhiannon Pugh, and Mika Raunio. 2017. Transformation of regional innovation policies: From traditional to next generation models of incubation. European Planning Studies 25: 620-37. [CrossRef]

Kroll, Henning. 2016. Policy Brief on Smart Specialisation. Fraunhofer ISI. November. Available online: http://s3platform.jrc.ec.europa.eu/documents/20182/196760/Policy+Brief+on+Smart+Specialisation/ 938913ba-040f-4d67-bb07-383e45ffaf0b (accessed on 5 June 2020).

Langley, Ann, and Chahrazad Abdallah. 2011. Templates and Turns in Qualitative Studies of Strategy and Management. In Research Methodology in Strategy and Management. Bingley: Emerald, vol. 6. [CrossRef]

Leydesdorff, Loet, and Henry Etzkowitz. 2003. Can "the public" be considered as a fourth helix in UniversityIndustry-Government relations? Report of the Fourth Triple Helix Conference. Science E Public Policy 30: 55-61.

Lundvall, Bengt-Ake. 2010. National Systems of Innovation: Toward a Theory of Innovation and Interactive Learning. London and New York: Anthem Press. 
MacGregor, Steven P., Pilar Marques-Gou, and Alexandra Simon-Villar. 2010. Gauging Readiness for the Quadruple Helix: A Study of 16 European Organizations. Journal of the Knowledge Economy 1: 173-90. [CrossRef]

Marinelli, Elisabetta, and Inmaculada Perianez Forte. 2017. Smart Specialisation at Work: The Entrepreneurial Discovery as a Continuous Process. JRC Technical Reports, S3 Working Paper Series No. 12/2017. Luxemburg: Publications office of the European Union.

Miller, Kristel, Rodney McAdam, and Maura McAdam. 2018. A systematic literature review of university technology transfer from a quadruple helix perspective: Toward a research agenda. RED Management 48: 7-24.

Morgan, Kevin. 2016. Collective entrepreneurship: The Basque model of innovation. European Planning Studies 24: 1544-60. [CrossRef]

Panori, Anastasia, Christina Kakderi, Nicos Komninos, Katharina Fellnhofer, Alasdair Reid, and Luca Mora. 2020. Smart systems of innovation for smart places: Challenges in deploying digital platforms for co-creation and data-intelligence. Land Use Policy. in press. [CrossRef]

Ranga, Marina, and Henry Etzkowitz. 2013. Triple Helix Systems: An Analytical Framework for Innovation Policy and Practice in the Knowledge Society. Industry and Higher Education 27: 237-62. [CrossRef]

Ranga, Marina, and Ludovit Garzik. 2015. From Mozart to Schumpeter: A Triple Helix Systems approach to advancing regional innovation in the Salzburg region of Austria. In Austrian Council for Research and Technology Development, 2015 ed. Designing the Future: Economic, Societal and Political Dimensions of Innovation. Vienna: Echomedia Buchverlag, August.

Rodríguez-Pose, Andrés, and Callum Wilkie. 2016. Institutions and the Entrepreneurial Discovery Process for Smart Specialization in Governing Smart Specialisation. Edited by D. Kyriakou, M. Palazuelos Martinez, I. Periáñez-Forte and A. Rainoldi. London: Routledge.

Roman, Mona, and Timo Nyberg. 2017. Openness and Continuous Collaboration as the Foundation for Entrepreneurial Discovery Process in Finnish Regions. Management Dynamics in the Knowledge Economy 5: 517-31. [CrossRef]

Schoonmaker, Mary, and Elias Carayannis. 2013. Mode 3: A Proposed Classification Scheme for the Knowledge Economy and Society. Journal of the Knowledge Economy 4: 556-77. [CrossRef]

Sunne Municipality. 2011. Metodutveckling. Available online: https://sunne.se/globalassets/upload/projekt/ geniusloci/metodutvecklinggl.pdf (accessed on 5 June 2020).

Sunne Municipality. 2014. Vision för ny kommunstrategi 2014-2025. Available online: https://sunne.se/globalassets/ upload/politik-och-medborgardialog/policy-och-projekt/vision-for-ny-kommunstrategi_140526.pdf (accessed on 5 June 2020).

Sunne Municipality. 2018. Sunne is developing citizen dialogue. In Curious about Sunne? April 4. Available online: https://sunne.se/globalassets/upload/naringsliv/naringsliv/inflyttning/nyfiken-pa-sunne2018/curious-about-sunne-nr-1-2018-engelska.pdf (accessed on 5 June 2020).

Todeva, Emanuela, and Panayiotis Ketigidis. 2017. Regional entrepreneurship and innovation management: Actors, helices and consensus space. Management Dynamics in the Knowledge Economy 5: 57-76. [CrossRef]

Tödtling, F., and M. Trippl. 2011. Regional Innovation Systems. In Handbook of Regional Innovation and Growth. Edited by P. Cooke, B. Asheim, R. Boschma, R. Martin, D. Schwartz and F. Tödtling. Cheltenham: Edward Elgar, pp. 455-66.

Uotila, Tuomo, Vesa Harmaakorpi, and Raine Hermans. 2012. Finnish mosaic of regional innovation system-Assessment of thematic regional innovation platforms based on relational variety. European Planning Studies 20: 1583-602. [CrossRef]

van der Have, Robert P., and Luis Rubalcaba. 2016. Social innovation research: An emerging area of innovation studies? Research Policy 45: 1923-35. [CrossRef]

Värmland Region. 2015. Värmland's Research and Innovation Strategy for Smart Specialisation 2015-2020. Available online: https://www.regionvarmland.se/globalassets/global/utveckling-och-tillvaxt/naringslivforskning-innovation/vris3.pdf (accessed on 5 June 2020).

Virkkala, Seija, Antti Mäenpää, and Åge Mariussen. 2017. A connectivity model as a potential tool for smart specialization strategies. European Planning Studies 25: 661-79. [CrossRef] 
Yawson, Robert M. 2009. The Ecological System of Innovation: A New Architectural Framework for a Functional Evidence-Based Platform for Science and Innovation Policy. Paper presented at the Future of Innovation Proceedings of the XX ISPIM 2009 Conference, Vienna, Austria, June 21-24, pp. 1-16. [CrossRef]

Yin, Robert K. 2009. Case study research: Design and methods/Robert K. Yin. Applied Social Research Methods Series 5: 282. [CrossRef]

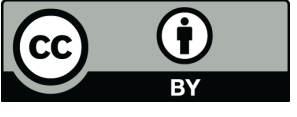

(C) 2020 by the authors. Licensee MDPI, Basel, Switzerland. This article is an open access article distributed under the terms and conditions of the Creative Commons Attribution (CC BY) license (http://creativecommons.org/licenses/by/4.0/). 